\title{
The Role of Pre-ablative Stimulated Thyroglobulin and Thyroglobulin/ Thyroid-Stimulating Hormone Ratio for Predicting Metastasis in Thyroid Cancer
}

\author{
Tiroid Kanserinde Pre-ablatif Stimüle Tiroglobulin ve Tiroglobulin/Tiroid Uyarıcı Hormon \\ Oranının Metastaz Tahminindeki Rolü
}

\author{
(1) Fadime Demir1, (1) Fikri Selçuk Şimşek2, (1) Tansel Ansal Balcı²
}

ITokat Gaziosmanpaşa University Faculty of Medicine, Department of Nuclear Medicine, Tokat, Turkey

2Firat University Faculty of Medicine, Department of Nuclear Medicine, Elazı̆̆, Turkey

\begin{abstract}
Objectives: In this study, we aimed to investigate the predictive value of pre-ablative stimulated thyroglobulin $(\mathrm{Tg})$ and $\mathrm{Tg} / \mathrm{thyroid}$-stimulating hormone (TSH) to identify lymph node metastasis (LNM) or distant metastases (DM) prior to radioactive iodine (RAI) treatment.

Methods: Patients without metastasis were included in group $1(n=100)$, those with LNM were included in group 2 ( $n=83$ ), and those with DM constituted group $3(n=23)$. Tg and TSH values were measured approximately 4 hours prior to RAl ablation therapy.

Results: There was a significant difference between group 3 and other groups (group 1 and group 2) in terms of $\mathrm{Tg}(\mathrm{p}<0.001)$ and $\mathrm{Tg} /$ TSH ( $p<0.001)$. For Tg level and Tg/TSH ratio, the areas under ROC were 0.990 [95\% confidence interval (Cl): 0.979-1] and 0.991 (95\% Cl: $0.981-1$ ), respectively. The cut-off points for $\mathrm{Tg}$ and $\mathrm{Tg} / \mathrm{TSH}$ were $102 \mathrm{ng} / \mathrm{mL}$ and 1.06 , respectively.

Conclusion: Our results suggest that $\mathrm{Tg}$ and $\mathrm{Tg} / \mathrm{TSH}$ values can be used to predict DM. On the other hand, our study indicates that patients should be carefully evaluated for LNM even when Tg levels are low.

Keywords: Thyroid cancer, thyroglobulin, metastasis
\end{abstract}

Öz

Amaç: Bu çalışmada, radyoaktif iyot (RAi) tedavisi öncesi lenf nodu metastazını veya uzak metastazları belirlemek için pre-ablatif stimüle tiroglobulin (Tg) ve Tg/tiroid-uyarıı hormonun (Tg/TSH) prediktif değerini araştırmayı amaçladık.

Yöntem: Grup 1'e $(n=100)$ metastaz saptanmayan hastalar, grup 2'ye ( $n=83)$ lenf nodu metastazı olan hastalar ve grup 3'e ( $n=23)$ uzak metastazı olan hastalar dahil edildi. Tg ve TSH değerleri RAi tedavisinden yaklaşık 4 saat önce ölçüldü.

Bulgular: Grup 3 ile diğer gruplar (grup 1 ve grup 2) arasında Tg $(p<0,001)$ ve Tg/TSH $(p<0,001)$ açısından anlamlı fark vardı. Tg seviyesi ve Tg/TSH oranı için ROC eğrisi altındaki alanlar sırasıyla 0,990 (\%95 güven aralığı: 0,979-1) ve 0,991 (\%95 güven aralığı: 0,981-1) idi. Tg ve Tg/ TSH için kesme noktaları sırasıyla $102 \mathrm{ng} / \mathrm{mL}$ ve $1,06 \mathrm{ng} / \mathrm{mL}$ idi.

Sonuç: Çalışmamıza göre Tg ve Tg/TSH değerleri uzak metastaz için prediktif bir değer olarak kullanılabilir. Öte yandan, çalısmamız lenf nodu metastazının düşük Tg seviyelerinde bile dikkatli bir şekilde değerlendirilmesi gerektiğini düşündürmektedir.

Anahtar kelimeler: Tiroid kanseri, tiroglobulin, metastaz

Address for Correspondence: Fadime Demir MD, Tokat Gaziosmanpaşa University Faculty of Medicine, Department of Nuclear Medicine, Tokat, Turkey Phone: +90 5304197080 E-mail: drfadimedemir@hotmail.com ORCID ID: orcid.org/0000-0002-9799-6398 Received: 21.11.2018 Accepted: 12.03.2019 


\section{Introduction}

Thyroid cancer is the most common endocrine malignancy worldwide, with a rapidly inceraseing incidence rate (1). Thyroid carcinomas are classified as differentiated or undifferentiated according to their histologic type. Differentiated thyroid carcinomas (DTC) account $>90 \%$ of thyroid cancer. The standard treatments for DTC include total thyroidectomy (TT), radioactive iodine (RAI) ablation therapy (patients with a tumor $>1 \mathrm{~cm}$ in size) and long-term thyroid stimulating hormone (TSH) suppression therapy (2). DTC has a relatively good prognosis with 10-year survival rates of $92-98 \%$. Nevertheless, cervical lymph node metastases (LNM) develop in 53\% and distant metastases (DM) in $10 \%$ of patients $(3,4)$. The RAI dose to administer can be chosen either empirically $(100-200 \mathrm{mCi})$ or by lesional or whole-body dosimetry if available, in order to limit the whole-body retention to $80 \mathrm{mCi}$ at 48 hours and 200 cGy to the bone marrow (5). The most common method is empiric administration in which the radioiodine dose is based primarily on the extent of the tumor. The potential disadvantage of empiric dosing is that individual patients may be under- or over-dosed (6). Presence of LNM and DM are significant determinants for empirical dose planning. LNM or DM can be detected by using clinical evaluation, as well as surgical, radiological and diagnostic iodine-131 (I-131) whole-body scan (WBS) findings. However, it will be more appropriate if diagnostic tools are performed after a risk assessment or clinical suspicion. Thyroglobulin $(\mathrm{Tg})$ is the specific marker of thyroid tissue. Tg levels significantly decrease after surgical removal of thyroid tissue, while $\mathrm{Tg}$ levels remain high in case of residual tissue or DM in thyroid cancer (7). Endogenous TSH can stimulate Tg release from the thyroid bed or metastatic tissue. Endogenous TSH induce $\mathrm{Tg}$ release from thyroid bed or metastatic tissue. This means that the $\mathrm{Tg}$ release is dependent by TSH (8). The aim of this study was to investigate the potential value of pre-ablative stimulated $\mathrm{Tg}$ and $\mathrm{Tg} / \mathrm{TSH}$ to identify LNM or DM prior to RAI treatment.

\section{Materials and Methods}

\section{Patients}

Patients treated with RAl for thyroid cancer in Firat University Hospital between 2012 and 2018 were reviewed in this retrospective analysis. One hundred patients without metastasis were included in group 1, eighty-three patients with lymph node metastasis were included in group 2 and 23 patients with DM were included in group 3. Metastasis was diagnosed by pathologic involvement in whole body RAl scan after treatment, with or without positive findings on other imaging modalities [computed tomography $(\mathrm{CT})$, magnetic resonance (MR), and positron emission tomograph/CT]. Patients with positive anti-Tg antibodies (TgAb) were excluded from the study, since their Tg levels could have been affected. This retrospective analysis has been approved by the Firat University Research Committee (06.09.2018/14-10).

\section{Radioiodine Therapy and Follow-up}

Thyroid hormone replacement was withdrawn for 3-4 weeks prior to RAI treatment, and patients' TSH levels were increased over $30 \mathrm{IU} / \mathrm{mL}$ if possible. Patients followed a low-iodine diet for 10 days before I-131 treatment. The doses of radioiodine were determined by performing postop neck ultrasonography (USG) with or without MR, TC$99 \mathrm{~m}$ thyroid scan, along with $\mathrm{Tg}$ values. For radioiodine ablation, a dose of $3.7 \mathrm{GBq}$ was administered to eliminate thyroid remnants. When lymph node metastases were detected, patients were treated with radioiodine at a dose of $5.55 \mathrm{GBq}$. If DM was detected, patients were treated with radioiodine at a dose of $7.4 \mathrm{GBq}$. I-131 WBS was performed 7-8 days after treatment of I-131.

\section{$\mathrm{Tg}$ and TSH Measurement}

$\mathrm{Tg}$ and TSH were measured approximately 4 hours before RAI administration. Tg levels were determined by chemiluminescence immunoassay $\left(\right.$ IMMULITE ${ }^{\circledR} 2000$ XPi Immunoassay System, US/Wales, UK). Measuring ranges were 0.20 to $30000 \mathrm{ng} / \mathrm{mL}$ (with 1/100 dilution). TSH levels were determined by chemiluminescence immunoassay (ADVIA Centaur CP Immunoassay System/US) Measuring ranges were 0.010 to $150 \mu \mathrm{lU} / \mathrm{L}$. TgAb were determined by chemiluminescence microparticle immunoassay (ARCHITECT i2000SR). Measuring ranges were 20 to 1000 $\mathrm{IU} / \mathrm{mL}$. Positivity for TgAb was accepted as more than 40 $\mathrm{IU} / \mathrm{mL}$, and patients with $\mathrm{TgAb}$ levels above $40 \mathrm{IU} / \mathrm{mL}$ were excluded from the study.

\section{Statistical Analysis}

Continuous variables are reported as mean \pm standard deviation or median values and ranges, while categorical variables are reported as absolute numbers. Between groups, differences were assessed with the Kruskal-Wallis test (and Mann-Whitney $U$ pair-wise comparisons) or the chi-square test (categorical variables). A p value less than 0.05 was considered as significant. Receiver-operating characteristic (ROC) curve analysis was used to define the best cut-off value for serum $\mathrm{Tg}$ in terms of showing the presence of metastases. For the established cut-off value, we calculated the sensitivity, specificity, and area under the curve (AUC). All analyses were performed with SPSS Software (version 20.0). 


\section{Results}

Of the 206 patients included in the study, 155 were female and 51 were male. The mean age was $45.88 \pm 13.59$. Characteristics of study subjects are presented in Table 1.

There was a significant difference between group 3 and other groups (group 1 and group 2) in terms of $\mathrm{Tg}$ $(p<0.001)$ and Tg/TSH $(p<0.001)$. In group 3, Tg and Tg/ TSH were higher than the other groups. But there was no significant difference between group 1 and group 2 (Figure1). There was also a significant difference in terms of gender $(p<0.001)$ and age $(p<0.001)$ between groups (Table 2). In group 3, the tumor size was significantly lower than group 1 and group $2(p<0.001)$.

The diagnostic accuracy of serum $\mathrm{Tg}$ and $\mathrm{Tg} / \mathrm{TSH}$ was evaluated using ROC analysis. The ROC curve is illustrated in Figure 2. The areas under ROC for Tg level and Tg/TSH ratios were 0.990 [95\% confidence interval $(\mathrm{Cl})$ : 0.9791] and 0.991 (95\% Cl: 0.981-1), respectively. The cut-off

\section{Table 1. Characteristics of study subjects}

\begin{tabular}{|c|c|}
\hline Age (mean $\pm S D)$ & $45.88 \pm 13.59$ \\
\hline $\begin{array}{l}\text { Gender n (\%) } \\
\text { Male } \\
\text { Female }\end{array}$ & $\begin{array}{l}51(24.8 \%) \\
155(75.2 \%)\end{array}$ \\
\hline $\begin{array}{l}\text { Pathology n (\%) } \\
\text { Papillary } \\
\text { Follicular } \\
\text { Hurthle cell } \\
\text { Poorly } \\
\text { differentiated }\end{array}$ & $\begin{array}{l}180(87.4 \%) \\
10(4.9 \%) \\
7(3.4 \%) \\
9(4.4)\end{array}$ \\
\hline $\begin{array}{l}\text { Tumor size mm } \\
\text { (median/min-max) }\end{array}$ & $12(0.5-100)$ \\
\hline $\begin{array}{l}\text { Metastasis } \\
\text { localization } \\
\text { Lymph node } \\
\text { Cervical } \\
\text { Mediastinal } \\
\text { Cervical + } \\
\text { mediastinal } \\
\text { Submental } \\
\text { Supraclavicular } \\
\text { Distant metastasis } \\
\text { Lung } \\
\text { Bone } \\
\text { Multiple organ } \\
\text { metastasis }\end{array}$ & $\begin{array}{l}63(76 \%) \\
10(12 \%) \\
5(6 \%) \\
1(1.2 \%) \\
4(4.8 \%) \\
13(56.5 \%) \\
7(30.5 \%) \\
3(13 \%)\end{array}$ \\
\hline $\begin{array}{l}\mathrm{Tg}(\mathrm{ng} / \mathrm{mL}) \\
\text { (median/min-max) }\end{array}$ & $7.32(0.1-30000)$ \\
\hline $\begin{array}{l}\text { TSH (IU/mL) } \\
\text { (median/min-max) } \\
\text { Tg/TSH (median/ } \\
\text { min-max) }\end{array}$ & $\begin{array}{l}75(23-150) \\
0.093(0.001-41.74)\end{array}$ \\
\hline
\end{tabular}

SD: Standard deviation, Tg: Thyroglobulin, TSH: Thyroid-stimulating hormone, Min: Minimum, Max: Maximum
A

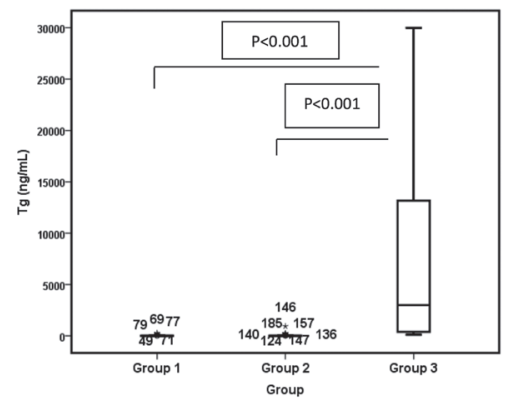

B

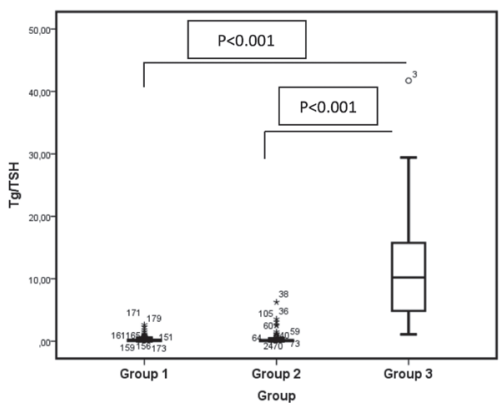

$\mathrm{C}$

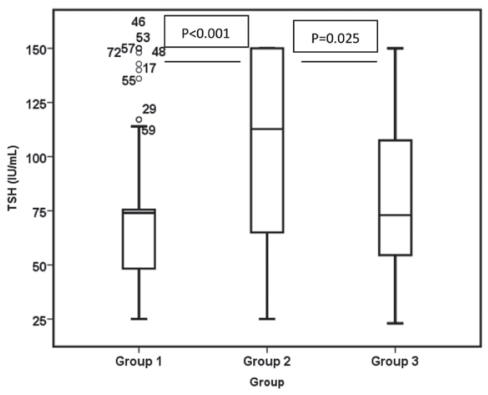

$\mathrm{D}$

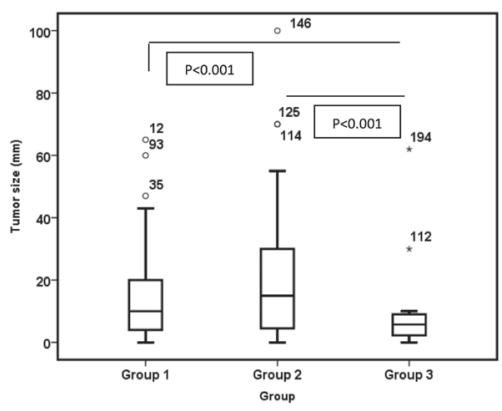

Figure 1. Association of characteristics between groups by Kruskal-Wallis test and Mann-Whitney $U$ pair-wise comparisons: A) Comparison of groups in terms of thyroglobulin ( $\mathrm{Tg}$ ) values. B) Comparison of groups in terms of Tg/thyroid-stimulating hormone (TSH). C) Comparison of groups in terms of TSH. D) Comparison of groups in terms of tumor size 
point was specified from the ROC curve using the optimal intersection of specificity and sensitivity. Based on the drawn ROC curve, the cut-off point for Tg was at $102 \mathrm{ng} /$ $\mathrm{mL}$ (sensitivity; 100\%, specificity; $94.5 \%$ ) and for Tg/TSH was at 1.06 (sensitivity; 100\%, specificity; $92.3 \%$ ).

\section{Discussion}

LNM is known as a risk factor for poor clinical outcome in thyroid carcinoma. Decreased survival and increased mortality rates have been demonstrated among patients with DTC with lymph node metastasis (9). 10-15\% of patients with DTC present with or subsequently develop DM. In these patients, the 10-year disease-specific survival rate drops to $40 \%$ (10). Early detection and treatment have been found to have a substantial effect on the survival rate of patients with DTC (11). Detection of metastasis of DTC

Table 2. Comparison of characteristics between groups

\begin{tabular}{lllll}
\hline Characteristics & $\begin{array}{l}\text { Group 1 } \\
(\mathbf{n = 1 0 0 )}\end{array}$ & $\begin{array}{l}\text { Group 2 } \\
(\mathbf{n = 8 3 )}\end{array}$ & $\begin{array}{l}\text { Group 3 } \\
(\mathbf{n = 2 3 )}\end{array}$ & $\mathbf{p}$ \\
\hline$<40$ years & $35(35 \%)$ & $34(41 \%)$ & $3(\% 13)$ & $0.046^{*}$ \\
$\geq 40$ years & $65(65 \%)$ & $49(59 \%)$ & $20(87 \%)$ & \\
Gender & & & & \\
Female & $87(87 \%)$ & $55(66.3 \%)$ & $13(56.5 \%)$ & $<0.001^{* *}$ \\
Male & $13(13 \%)$ & $28(33.7 \%)$ & $10(43.5 \%)$ & \\
\hline " $<<0.05, "$ "* $<0.001$ & & & &
\end{tabular}

\section{A}

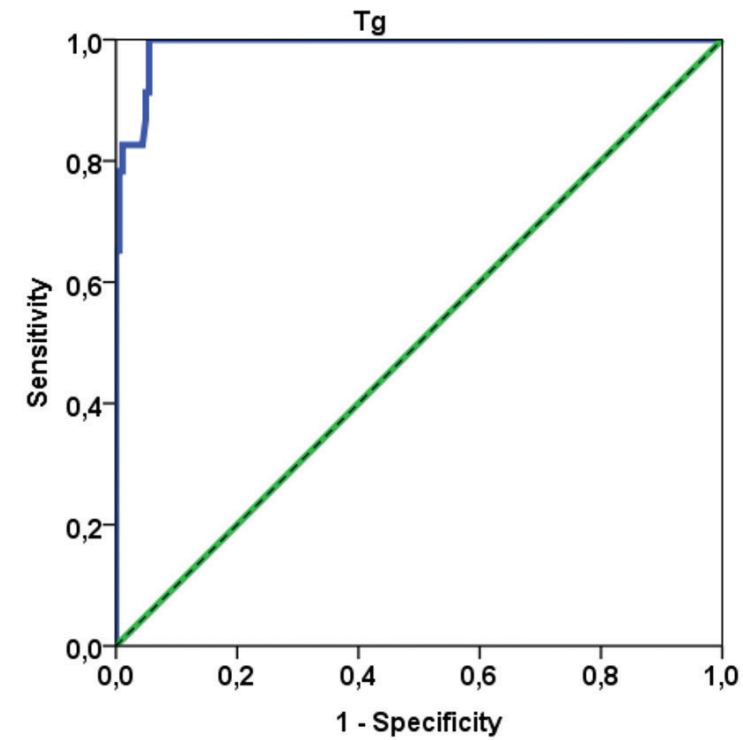

patients is important for better treatment planning. USG, chest radiography, CT, MR and diagnostic WBS are imaging modalities used for LNM and DM diagnosis. Nevertheless, sometimes it may not be visualized on these imaging techniques (11) and the metastasis can only be detected in WBS after treatment.

$\mathrm{Tg}$ is the specific marker of thyroid tissue. Tg levels significantly decrease after surgical removal of thyroid tissue, while Tg levels remain high in case of residual tissue or DM in thyroid cancer (7). Therefore Tg is a tumor marker for therapy monitoring and a significant parameter used in the follow-up of subjects with DTC. Excluding thyroid cell damage, two factors determine $\mathrm{Tg}$ concentration in most clinical situations. These factors are thyroid cell mass and activation of TSH receptors (12). TSH secretion induced by LT4 withdrawal increases the sensitivity of Tg measurement in terms of neoplastic tissue detection (13). Since TSH values of pre-ablative patients may be different, Tg values may also be affected accordingly. For this reason, in our study, we included $\mathrm{Tg} / \mathrm{TSH}$ ratio in our study parameters in addition to $\mathrm{Tg}$ to investigate the predictive value for metastasis in patients with DTC.

According to the results of our study; there was a significant difference between the group without metastasis and with DM in terms of both $\mathrm{Tg}$ and $\mathrm{Tg} / \mathrm{TSH}$ values. ROC analysis of $\mathrm{Tg}$ and $\mathrm{Tg} / \mathrm{TSH}$ also showed good accuracy (0.990 and

B

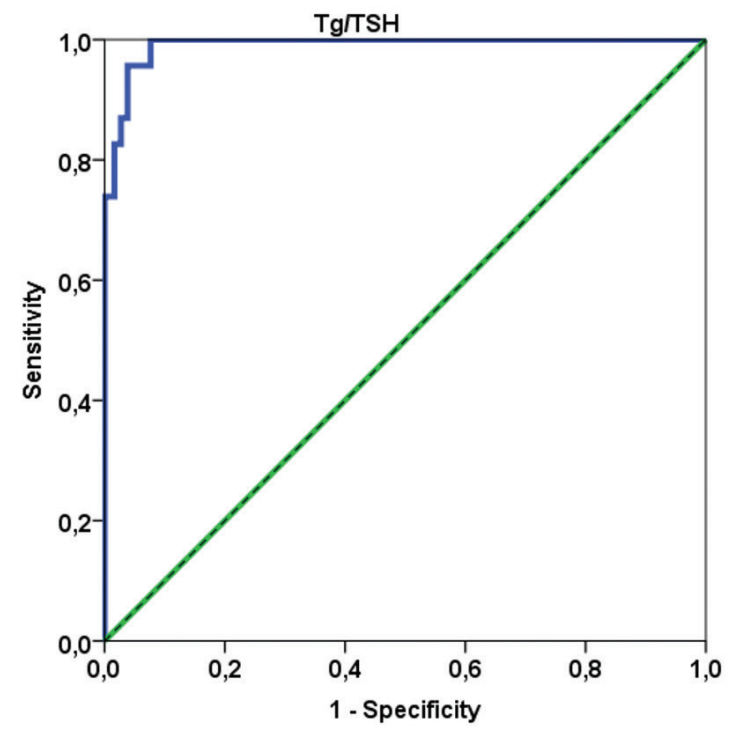

Figure 2. Receiving operator characteristic (ROC) curve for thyroglobulin (Tg) and Tg/thyroid-stimulating hormone (TSH) to detect distant metastatic differentiated thyroid carcinoma. A) ROC curve for Tg level. B) ROC curve for Tg/TSH ratio 
0.991) as diagnostic markers for DM. In a similar study by Lin et al. (14), they reported that both $\mathrm{Tg}$ and $\mathrm{Tg} / \mathrm{TSH}$ ratios could be considered predictors of DTC DM after TT prior to the first I-131 ablative therapy. Area under the ROC curve for Tg concentrations and Tg/TSH ratios were 0.913 and 0.916 , respectively, in this study.

In a study which investigates the value of pre-ablation stimulated Tg in predicting DM of papillary thyroid cancer (15), it was reported that area under the ROC curve for $\mathrm{Tg}$ levels was 0.893 and the cut-off value of Tg was $52.75 \mu \mathrm{g} / \mathrm{L}$ with a sensitivity of $78.90 \%$ and specificity of $91.70 \%$. In our study, we found that the areas under ROC for Tg level was 0.990, the cut-off point for $\mathrm{Tg}$ was at $102 \mathrm{ng} / \mathrm{mL}$. We think that this difference in Tg cut-off may be related to the Tg measurement method.

In an analysis of $\mathrm{Tg}$ doubling time (Tg-DT), which is the time required to double the amount of Tg, Rössing et al. (16) have suggested that Tg-DT is not a single predictor of progressive disease but that it creates significant differences in the survival of patients with high tumor burden in patients with progressive DTC. They reported that there is a significant difference in survival rates patients with $\mathrm{Tg}$ levels greater than $100 \mathrm{ng} / \mathrm{mL}$ and with $\mathrm{Tg}$ levels lower than $100 \mathrm{ng} / \mathrm{mL}$. This result suggested that one of the reasons for the difference in survival rate detected in their study might be DM. Zhao et al. (17) suggested that pre-ablative Tg levels may be affected by TSH and residual tissue after surgery, therefore, the difference between serial Tg measurements (at an average 8-day interval) could be a better marker of DM. The area under the ROC curve for $\Delta \operatorname{Tg}(\Delta \mathrm{Tg}<0, \Delta \mathrm{Tg}>0)$ and $\Delta \mathrm{Tg} / \Delta \mathrm{TSH}(\Delta \mathrm{Tg} / \Delta \mathrm{TSH}<0, \Delta \mathrm{Tg} /$ $\Delta \mathrm{TSH}>0$ ) parameters in their study was $0.907,0.856$ and $0.911,0.905$, respectively. Based on the drawn ROC curve, the cut-off point for $\Delta \mathrm{Tg}$ was at $-6.55-3.90 \mathrm{ng} / \mathrm{mL}$ and for $\Delta \mathrm{Tg} / \Delta \mathrm{TSH}$ was at $-0.40-0.41 \mathrm{ng} / \mu \mathrm{lU}$.

In our study, there was no significant difference between patients with lymph node metastasis and those without metastasis in terms of $\mathrm{Tg}$ and $\mathrm{Tg} / \mathrm{TSH}$ values. This result suggests that these parameters could not be used to predict LNM. In the literature, the group of patients with metastasis are classified as those with combined lymph node and DM or with DM alone. To the best of our knowledge, there aren't any studies comparing patients with and without lymph node metastases in terms of postoperative stimulated $\mathrm{Tg}$ values. Ronga et al. (18) reported that the mean Tg value was not significantly different between those with lymph node metastases and those with DM. In our study, both $\mathrm{Tg}$ and $\mathrm{Tg} / \mathrm{TSH}$ values were significantly different between these two groups.

\section{Conclusion}

In conclusion, our results suggest that preablative $\mathrm{Tg}$ and $\mathrm{Tg} / \mathrm{TSH}$ values can be used to estimate DM. On the other hand, these values do not contribute significantly to the estimation of lymph node metastasis; therefore, we think that patients should be evaluated carefully for LNM even if their Tg levels are low.

\section{Ethics}

Ethics Committee Approval: This retrospective analysis has been approved by the Firat University Research Committee (06.09.2018/14-10).

Informed Consent: Retrospective study.

Peer-review: Externally and internally peer-reviewed.

\section{Authorship Contributions}

Surgical and Medical Practices: F.D., F.S.Ş., T.A.B., Concept: F.D., F.S.Ş., T.A.B., Design: F.D., F.S.Ş., T.A.B., Data Collection or Processing: F.D., F.S.S., T.A.B., Analysis or Interpretation: F.D., F.S.Ş., T.A.B., Literature Search: F.D., F.S.Ş., T.A.B., Writing: F.D., F.S.Ş., T.A.B.

Conflict of Interest: No conflict of interest was declared by the authors.

Financial Disclosure: The authors declared that this study received no financial support.

\section{References}

1. Siegel RL, Miller KD, Jemal A. Cancer statistics, 2016. CA Cancer J Clin 2016;66:7-34.

2. McLeod DS, Sawka AM, Cooper DS. Controversies in primary treatment of low-risk papillary thyroid cancer. Lancet 2013;381:10461057.

3. Mitchell AL, Gandhi A, Scott-Coombes D, Perros P. Management of thyroid cancer: United kingdom national multidisciplinary guidelines. Laryngol Otol 2016;130:S150-S160.

4. Durante C, Haddy N, Baudin E, Leboulleux S, Hartl D, Travagli JP, Caillou B, Ricard M, Lumbroso JD, De Vathaire F, Schlumberger M. Long-Term Outcome of 444 Patients with Distant Metastases from Papillary and Follicular Thyroid Carcinoma: Benefits and Limits of Radioiodine Therapy. J Clin Endocrinol Metab 2006;91:2892-2899.

5. Haugen BR, Alexander EK, Bible KC, Doherty GM, Mandel SJ, Nikiforov YE, Pacini F Randolph GW, Sawka AM, Schlumberger M, Schuff KG, Sherman SI, Sosa JA, Steward DL, Tuttle RM, Wartofsky L. 2015 American Thyroid Association Management Guidelines for Adult Patients with Thyroid Nodules and Differentiated Thyroid Cancer: The American Thyroid Association Guidelines Task Force on Thyroid Nodules and Differentiated Thyroid Cancer. Thyroid 2016;26:1-133.

6. Amdur RJ, Dan T, Mazzaferri E. Absence of Bone Marrow Toxicity in Elderly Patients Treated With Recombinant Human Thyroidstimulating Hormone and Empirically Dosed Radioiodine for Thyroid Cancer. Am J Clin Oncol 2013;36:348-353.

7. Tian JJ, Tao R, Shen YF, Xia SY, Li C. Correlation of serum thyroglobulin and anti-thyroglobulin antibody levels with pulmonary metastasis and bone metastasis in patients with thyroid cancer. Journal of Hainan Medical University 2017;23:101-104.

8. Spencer CA, Lopresti JS, Fatemi S, Nicoloff JT. Detection of 
Residual and Recurrent Differentiated Thyroid Carcinoma by Serum Thyroglobulin Measurement. Thyroid 1999;9:435-441.

9. Cao CJ, Dou CY, Lian J, Luan ZS, Zhou W, Xie W, Chen L, Zhou K Lai H. Clinical outcomes and associated factors of radioiodine-131 treatment in differentiated thyroid cancer with cervical lymph node metastasis. Oncol Lett 2018;15:8141-8148.

10. Kim DH, Jung JH, Son SH, Kim CY, Hong CM, Jeong SY, Lee SW, Lee J, Ahn BC. Difference of Clinical and Radiological Characteristics According to Radioiodine Avidity in Pulmonary Metastases of Differentiated Thyroid Cancer. Nucl Med Mol Imaging 2014;48:5562.

11. Qutbi M, Shafeie B, Amoui M, Tabeie F, Azizmohammadi Z, Mahmoud-Pashazadeh A, Javadi H, Assadi M, Asli IN. Evaluation of Prognostic Factors Associated With Differentiated Thyroid Carcinoma With Pulmonary Metastasis. Clin Nucl Med 2016:41:917-921.

12. Giovanella L, Ceriani L, Suriano $S$, Ghelfo $A$, Maffiolis $M$. Thyroglobulin measurement before rhTSH-aided 131 I ablation in detecting metastases from differentiated thyroid carcinoma. Clin Endocrinol 2008;69:659-663.

13. Schlumberger $M$, Baudin E. Serum thyroglobulin determination in the follow-up of Patients with differentiated thyroid carcinoma. Eur J Endocrinol 1998;138:249-252.

14. Lin Y, Li T, Liang J, Li X, Qiu L, Wang S, Chen Y, Kang Z, Li F. Predictive
Value of Preablation Stimulated Thyroglobulin and Thyroglobulin/ Thyroid-Stimulating Hormone Ratio in Differentiated Thyroid Cancer. Clin Nucl Med 2011;36:1102-1105.

15. Li T, Lin Y, Liang J, Li X, Qiu L, Wang S, Chen Y, Kang Z, Li F. The value of pre-ablation stimulated thyroglobulin in predicting distant metastasis of papillary thyroid cancer. Chin J Nucl Med Mol Imaging 2012;32:189-191.

16. Rössing RM, Jentzen W, Nagarajah J, Bockisch A, Görges R. Serum Thyroglobulin Doubling Time in Progressive Thyroid Cancer. Thyroid 2016;26:1712-1718.

17. Zhao T, Liang J, Li T, Gao W, Lin Y. Serial stimulated thyroglobulin measurements are more specific for detecting distant metastatic differentiated thyroid cancer before radioiodine therapy. Chin J Cancer Res 2017;29:213-222.

18. Ronga G, Filesi M, Ventroni G, Vestri AR, Signore A. Value of the first serum thyroglobulin level after total thyroidectomy for the diagnosis of metastases from differentiated thyroid carcinoma. Eur J Nucl Med 1999;26:1448-1452. 